\title{
BAFRA'DA FIYATLAR VE ÜCRETLER (1914-1930)
}

\section{NEDIM IPEK*}

1914-1930 yılları arası Türk tarihi açısından oldukça önemlidir. Bu dönemin siyasî ve askerî özellikleri kaynaklara istinaden birçok arașturmayla ortaya konulmaya çalışılmıştur. Sosyal ve ekonomik yönlerini ele alan araşturmalar ise oldukça sınırlıdır. Oysa, dönemin olaylarının daha iyi anlaşılabilmesi için ekonomik gelişimin yanı sıra gıda maddeleri ve tüketim mallarındaki fiyat hareketlerinin ortaya konması zarurîdir. Değişik tarihlerdeki fiyat hareketleri, narh defterlerine, sicillere, gazetelere ve konsolosluk raporlarma istinaden çeşitli çalışmalarda incelenmiştir. Fiyat hareketlerinin incelenmesinde faydalanılacak ana kaynaklardan birisi de Belediye Meclisi Karar Defterleri'dir. Bu defterlere istinaden yapılan çalışmalar yok denecek kadar azdır'.

Çalışmanın asıl kaynağını 1914-1930 tarihleri arasındaki kararları ihtiva eden üç ciltlik Bafra Belediye Meclisi Karar Defterleri oluşturmaktadır. İlk iki defter Arap harfleri ile üçüncü defter ise Arap ve Lâtin harfleriyle tutulmuştur. Kararlar, sivillerin vermiş oldukları dilekçeler ile belediye görevlileri veya resmî kurumların çeşitli konularda yazılı müracaatları üzerine alınmıstur. Kararlar, belediye bütçesi, beledî vergiler, narh ve rayiç mazbataları, esnafa verilen cezalar, aydınlatma, temizlik ve asayişle ilgilidir. Kararların alunda başkan ve azaların imza ve mühürleri bulunmaktadır.

Çalışma sahamızı teşkil eden Bafra kasabası Samsun şehrinin kuzey-bausında Kızılırmak'ın mansıbı itibarıyla iki km yukarısında kurulmuștur. XX. yüzyılın başlarında etrafı meyve ağaçlarıyla çevrili olup binalar taş ve ağaçtan inşa edilmiştir. 1915 yılı itibarıyla, 2.500 hanede 11.000 nüfuslu bir kasabadır'. Canik Mutasarrıfı Hamid Bey'in notlarma göre kasabanın 1919 tarihin-

" Ondokuzmayss Ünv. Fen-Edb. Fakūltesi Tarih Bölümü Öğretim Üyesi.

' Oktay Gökdemir, " Beledive Meclisi Kararlarına Göre İşgal Yillarında Akhisar'da Fiyatlar (1920-1922)", Cağdaş Türkiye Tarihi Araşurmaları Dergisi, I/1, İzmir 1991, 183-200.

${ }^{2}$ Mart 1331 tarihli karar: Bafia Belediye Meclisi Karar Defteri (BMKD), I, 75. 
deki nüfusu ise 8.316 idi $^{3}$. Başlıca ürünleri tütün, buğday, mısır, yulaf, arpa ve sebzedir. Havyar, balık yumurtası, tavuk, yumurta, deri, ceviz ve kereste ihraç ürünleri arasında yer alır'

\section{A- GIDA FIYATLARI}

1- Ekmek : Ekmek Türk sofrasının vazgeçilmez bir unsurudur. 1914-1930 tarihleri arasında Bafra kasabası halkı ekmek ihtiyacını çeşitli kaynaklardan karşılamaktaydı. Halkın bir kısmı ekmeği kendisi pişirmekteydi. Diğer grup ise yerli kadınlar tarafından pişirilen veya firınlarda üretilen ekmeği satun alıyordu. Kasabadaki askerî birliklerin ekmeği ise ahaliye ait firınlarda pişiriliyordu $\mathrm{u}^{5}$.

Kasaba dahilinde XX. yüzyılın başlarında 15 fırın, 1925 yılında ise günde toplam 700 ekmek üretebilecek kapasiteye sahip on üç firın bulunmaktaydı. Kadınların sattığı ekmekler yerli undan yapılırken firınlar fabrika mamulü birinci sınıf undan ekmek imal etmekle mükelleftiler ${ }^{i}$. Bu kurala riayet etmeyerek daha düşük dereceli undan ekmek pişirenler zabıta memurlarınca tespit edilmesi halinde para cezasına çarpurılmaktaydılar. Söz konusu ekmekler ise müsadere ediliyorlardı. Ancak, yapılan tahkikat sonucu düşük dereceli unun kullanılmasının kasdî olmadığı anlaşılırsa, firın sahibi herhangi bir cezaya çarptırılmazken söz konusu ekmekler Belediye Meclisi'nin tespit ettiği fiyatla halka satılmaktaydı. Gramajı noksan olan ekmekler müsadere edilerek yardıma muhtaç ahaliye ücretsiz dağıtılırken, sağlığa zararlı olanlar ise imha edilmekteydi? ${ }^{7}$.

Ekmek fiyatlan Belediye Meclisi'nce belirlenmekteydi. Fırın sahipleri, maliyetin artması halinde fiyatların tekrar ayarlanmasın talep etmekteydiler. Talep üzerine konuyu araştıran Belediye Meclisi maliyetin artığını belirlemesi halinde narhı yükseltiyordu. Belirlenen ekmek narhını yeterli bulmayan ekmekçi esnafı zaman zaman unları olduğu halde ekmek çıkarmayabiliyordu. Bu gibi esnafa sadece para cezası veriliyordu. Örneğin, Eylül 1916 ta-

${ }^{3}$ Halit Eken, "Samsun'da Asayişin Sağlanması Yolunda Mutasarrıf Hamid Bey'in Aldığı Tedbirler", 19 Mayıs ve Milli Mücadelede Samsun Sempozyumu Bildiriler 16-20 Mays 1914. Samsun 1914, s. 36.

'Trabzon Vilâyeti Salnamesi 1320, s. 89.

5 Eylül 1337 tarihli karar: BMKD, I, 188, 265/15.

' 21 Mart 1341 tarihli karar: BMKD, II, 106/10; Trabzon Vilayyeti Salnamesi 1320, s. 163.

${ }^{7} 16$ Nisan 1330, 3 Mart 1339, 4 Nisan 1339 tarihli kararlar: BMKD, I, 6/8, 293/1, 301/14. 
rihinde tayin olunan beş kuruşluk narhı yeterli bulmadıkları için üretimi durdurmak suretiyle ahaliyi ekmeksiz bırakan esnafa ceza kanununun 257. maddesi hükmünce 50 kuruş para cezası verildi.

Fırmlarda ücret karşılığı hamurkâr ve yevmiyeci ismiyle işçi çalıştırıldığı anlaşılmaktadır. Fırın sahipleri çalış̧ırdıkları işçiler için belediyeden ruhsat almak zorundaydılar. Ruhsatsız çalışan işçiler tespit halinde nakdî para cezasına çarpturılmaktaydılar". İşçi ücretleri ve bunların ekmeğin maliyetine tesirine dair elimizdeki kaynaklarda herhangi bir kayıt bulunmadığından ücret artışlarımın ekmeğin maliyetini ne ölçüde etkilediğini ortaya koyacak durumda değiliz.

Ekmek fiyatlarını etkileyen bir diğer unsur yakacak fiyatlarındaki artışır. Örneğin, Mart 1928'de Belediye Meclisi, mevsim dolayısıyla un ve odun fiyatlarının sürekli artması üzerine ekmeğin kilosunun geçici bir süre için 30 kuruştan satılmasına ve durumun ilgililere ve bütün ahaliye duyurulmasına karar verdi ${ }^{10}$.

Ekmek fiyatl xrının belirlenmesinde en önemli etken un fiyatlarındaki dalgalanma oldu. Şüphesiz unun maliyetini en fazla etkileyen unsur buğday, arpa ve mısır fiyatları ile navlun ücretlerindeki değişkenliktir. Bir nolu tabloda görüleceği üzere hububat fiyatlanı 1916-1924 yıllanı arasında on bir ile on üç kat artu".

Tablo I

Hububat Fiyatlan

(1916-1924)

\begin{tabular}{|l|l|l|l|l|l|}
\hline \multirow{2}{*}{$\begin{array}{l}\text { Hububatun } \\
\text { cinsi }\end{array}$} & \multirow{2}{*}{$\begin{array}{l}\text { Birim } \\
\text { miktarı }\end{array}$} & \multicolumn{4}{|c|}{ Yıllar } \\
\cline { 3 - 6 } & Kilo & 1916 & 1917 & 1918 & 1924 \\
\hline Buğday & Nilo & 1.12 & 15 & 13 \\
\hline Arpa & $"$ & 0.75 & 0.87 & 9 & 9 \\
\hline Mısır & $"$ & 0.87 & 1 & 10 & 10 \\
\hline Birim miktarına düşen fiyatlar kuruş olarak verilmiștir. \\
\hline
\end{tabular}

*9 Mart 1340 tarihli karar: BMKD, II, 37/40; 5 Eylül 1332 tarihli karar: BMKD, I, 160.

92 Nisan 1924 tarihli karar: BMKD. II, 52/77; 5 Kasım 1928 tarihli karar: BMKD, III, $13 / 528$.

10 1 Mart 1928 tarihli karar: BMKD. III, 56/79.

112 Subat 1331 tarihli karar: BMKD, 1, 136; 17 Mays 1340 tarihli karar: BMKD, II, 56/91. 
Unun maliyetini etkileyen bir diğer unsur öğütme masrafıdır. Kaza dahilinde un fabrikası ve yel değirmenleri olmayı köylerde karadere adı verilen su değirmenleri vardı. Bu değirmenlerde öğütme ücreti $1 / 16$ oranında aynî olarak alınmaktaydı. Başka bir ifadeyle 100 kiloda 6 kilo 250 gram un alınmaktaydı ${ }^{12}$. Buna değirmene getir götür nakil masrafının da ilâve edilmesi gerekmektedir. Ancak, bu değirmenler ahalinin ihtiyacını karşılayacak kapasitede değildi ${ }^{13}$. Bafra'da firınların imal ettiği has ekmeğin unu Vezirköprü kasabasındaki fabrikadan temin ediliyordu. Söz konusu unlar, her hafta Kızılırmak üzerinden kayıkçılar marifetiyle Bafra'ya naklediliyorlardı. Bir torba unun nakliye ücreti 60 kuruştu. Ancak, zaman zaman kayıç̧ı ve kayıkçı reisleri fahiş fiyatlar alabiliyorlard ${ }^{14}$.

Un fiyatlarındaki artıs şüphesiz ekmek fiyatlarının da yükselmesine sebebiyet veriyordu. Bir çuval has unun fiyat Nisan 1914 tarihinde 95 ile 108 kuruşa çıkınca has ekmeğin kıyyesi 63 ve yerli ekmeğin kıyyesi 53 paraya yükseldi $^{15}$. Kazanın un ihtiyacının temin edilebilmesi için her hafta en azından 250 torba unun Vezirköprü kasabasından Bafra'ya nakledilmesi gerekiyordu $^{16}$. Ancak, söz konusu nakliyat düzenli değildi. Aralık 1915 tarihi itibarıyla bir çuval unun fiyatı 145-150 kuruşa çıkınca ekmeğin kıyyesi 90 para oldu. Alınan tedbirlere rağmen un fiyatlarındaki artışın önüne geçilemediği için kısa bir süre sonra bir torba un 175 kuruşa, ekmeğin kıyyesi ise 105 paraya yükseldi ${ }^{17}$.

Un fiyatlarını kontrol altına alabilmek için narh uygulamasına geçildi. Fakat, belirlenen narh üzerinden Bafra kasabasına un ve zahire ithal edilemediği gibi, bazı esnaf da narha riayet etmedi. Sonuçta, kasaba dahilindeki fukaranın büyük bir kısmı un temin edebilmek için Bafra Belediyesi'nin kapısına yığıldı. Konuyu çözümleyebilmek amacıyla Belediye Meclisi'nde un tüccarları ile yapılan müşterek toplantıda piyasada bin çuvalı aşkın un bulunduğu, yeni gelen unun maliyeti ile evvelce tespit edilen narhın arasında büyük bir farkın oluştuğu anlaşıldı. Bunun üzerine narh uygulamasının kaldırılarak erzak satışının geçici bir süre serbest bırakılmasına karar verildi. (28 Aralık 1916) ${ }^{18}$.

\footnotetext{
12 30 Mart 1335 tarihli karar: BMKD, I, 203.

1321 Mart 1341 tarihli karar: BMKD, II, 106/10.

115 Subat 1340 tarihli karar: BMKD, II, 16/120.

15 19 Nisan 1330 tarihli karar: BMKD, I, $7 / 23$.

lii 2 Subat 1331 tarihli karar: BMKD. I, 134.

1730 Kânûn-ı evvel 1331 tarihli karar: BMKD, I, 132. 133.

I8 15 Kânûn-ı evvel 1332 tarihli karar: BMKD, I, 167.
} 
Serbest piyasa ekonomisi uygulaması bazı muhtekirlerin hile ve dolaplarından dolayı temel gıda maddelerinde görülen kıtlı̆ı ortadan kaldırmadığı gibi pahalılığın tahammül olunamaz bir noktaya gelmesine sebebiyet verdi. Bunun üzerine, 14 Ocak 1917 tarihli Belediye Meclisi kararıla, birinci sınıf un (çuvalı 350 kuruş), ikinci sınıf un (çuvalı 280 kuruş), halis birinci yerli un (batmanı 30 kuruş), arpa unu (batmanı 15 kuruş), mısır unu (batmanı 18 kuruş), âlâ buğday (ölçeği 20 kuruş), yulaf (ölçeği 12 kuruş), mercimek, nohut, fasulye ( kıyyesi 4 kuruş), pirinç (okkası 15 kuruş), bulgur (okkası 8 kuruş) ve âlâ tuzsuz yağ (okkası 23 kuruş) gibi gıda maddelerini kapsayacak bir şekilde tekrar narh uygulamasına geçildi. Belirlenen narhdan fazlaya erzak satan ve alanlar hakkında kanunî işlem yapılması ve iktisad-ı mahallîyi ihlâl ettikleri gerekçesiyle örfi idareye teslim edilmesi hususunda zabıta memurlarına gerekli tebligat yapılması kararlaştırıld ${ }^{19} .1924$ yılında da unda narh uygulaması mevcut olup, buna riayet etmeyenler para cezasına çarpurıldılar ${ }^{20}$.

Bafra kasabasımın un ve zahire ihtiyacını temin maksadıyla yerli tüccarlardan Kefelizâde Yusuf, Osman ve Halid Efendiler taraflarından hususî bir şirketin kurulmasına teşebbüs edildi. Dörder lira sermaye ile Zahire ve Dakik Şirketi namıla kurulacak olan şirket, Bafra kazasının genel ihtiyacını temin için herhangi bir menfaat gözetmeksizin savaş müddetince erzak ve zahire getirecekti. Yalnız her çuvalın fiyatına nakil ve sair masraflar karşılığı beş kuruş ilâve edilecekti. Bunun iki kuruşu nakliye esnasında meydana gelecek olan zarar ziyan karşılığı tutulacaktu. Herhangi bir zarar görülmediği takdirde bu fonda biriken paranın şehit çocuklarına dağıtılacağı taahhüt edilmekteydi. 2.100 lira sermaye ve Şirket-i Harbiyye namıla kurulması teklif edilen bir diğer şirket de hükümetin vereceği listeye göre yardıma muhtaç asker aileleri ile kimsesiz olanlara ve orduya sermayesine mal satmay ve elde edilen gelirin $1 / 5$ 'ini hastahaneye ve şehit çocuklarına vermeyi taahhüt ediyordu. Bu taleplerin incelenmesi için bir komisyonun oluşturulması kararlaşturıldı $^{21}$. Bu şirketlerin kurulduğuna dair bir kayda rastlayamadık. Ancak, Canik Sancağı dahilinde zahire ve erzak celbi ve uygun bir fiyatla dağıtımı amacıyla oluşturulan şirketler, kurucularının asıl amaçlarının askerlik hizmetini tecil etmek olduğu gerekçesiyle 22 Temmuz 1917 tarihli Mutasarrıflık emriyle lağvedildiler ${ }^{22}$.

1"' 1 Kânûn-ı sânî 1332 tarihli karar: BMKD, I, 162.

20 4 Mart/21 Nisan 1340 tarihli kararlar: BMKD, II, 35/18; 51/76.

212 Şubat 1332 tarihli karar: BMKD, I, 172.

${ }^{22}$ Canik Mutasarnfi'nun 15 Kânûn-ı sânî 1334 tarihli tezkiresi: Başbakanlık Osmanh Ałşivi (BA), Dahiliye Irade-i Umumiye (DH.I.UM), nr. 20-2/2-37. 
Temmuz-Ağustos 1917 tarihlerinde Bafra'nın bir aylık iaşe stoğu vardı. Mutasarnflık, Sancak dahilinde ileride herhangi bir sıkıntı çekilmemesi için kendi sermayeleri ile zahire getirmek üzere Amasya ve Çorum'a tüccarlar gönderdi. Ancak, Amasya ve Çorum Mutasarrıflıkları söz konusu nakliyata izin vermediler. Bunun sonucu olarak 20 Eylül 1917 tarihinde Samsun'da firınlar ekmek çıkaramadı ve iaşe darlığı had safhaya ulaştı. Sancak dahiline zahire nakli zorlaşukça ekmeğin okkası 80,90 ve hatta 100 kuruşa kadar yükseldi ${ }^{23}$.

Kasım 1918'den sonra piyasa fiyatlarında hissedilir oranda düşmeler başlayınca has ekmeğin kıyyesi 45 kuruşa, yerli ekmeğin kıyyesi 30 kuruşa, mısır ekmeğinin kıyyesi 20 kuruşa indirildi. İleriki tarihlerde birinci has ekmeğin kıyyesi 35 kuruşa, yerli ekmeğin kıyyesi ise 25 kuruşa düşürüldü. Aralık 1929 tarihinde ekmeğin fiyat 23 kuruş olarak belirlendi ${ }^{24}$.

\section{Tablo II}

\section{Bafra Belediye Meclisi Narh Mazbatalarına Göre Ekmek Fiyatlan}

(1914-1929)

\begin{tabular}{|l|l|l|l|}
\hline Tarih & Kuruş & Tarih & Kuruş \\
\hline Nisan 1914 & 1.57 & Mayıs 1923 & 22 \\
\hline Aralık 1915 & 2.25 & Şubat 1924 & 22 \\
\hline Eylül 1916 & 5 & Ocak 1925 & 30 \\
\hline Ekim 1918 & 35 & Ağustos-Eylül 1925 & 28 \\
\hline Kasım 1918 & 45 & Eylül 1927 & 24 \\
\hline Mayıs 1919 & 35 & Ekim 1927 & 26 \\
\hline Eylül 1919 & 20 & Aralık 1928 & 29 \\
\hline Eylül 1920 & 20 & Ocak 1929 & 29 \\
\hline Şubat 1921 & 23 & Mart 1929 & 27 \\
\hline Ekim 1922 & 22 & Temmuz 1929 & 24 \\
\hline Nisan 1923 & 25 & Aralık 1929 & 23 \\
\hline Birim miktarı kıyye. & & \\
\hline
\end{tabular}

23. Canik Mutasarrıfi'nun 15 Kânûn-ı sânî 1334 tarihli tezkiresi: BA, DH.İ.UM, nr. 20-2/2. 37.

217 Teşrîn-i sânî 1334 tarihli karar: BMKD, I, 186; 8 Ekim 1927 tarihli karar: BMKD, III. $4 / 501$. 
Netice itibarıyla, savaş döneminde ekmeğin kıyyesi 63 paradan 45 kuruşa kadar yükseldi. Savaşın fiilen sona ermesi ile fiyatlarda hızlı bir düşüş başladı. İleriki tarihlerde hububat hasadına göre inişli çıkışı bir seyir takip eden ekmeğin kilosu Mayss 1930 tarihinde 16 kuruş seviyelerinde idi.

Tablo III

Bafra Belediyesi Rayiç Mazbatalanna Göre Ekmek Fiyatlan (1914-1930)

\begin{tabular}{|l|l|l|l|}
\hline Tarih & Kuruş & Tarih & Kuruş \\
\hline Nisan 1914 & 1.22 & Ocak-Şubat 1924 & 19.50 \\
\hline Aralık 1915 & 1.75 & Nisan 1924 & 20 \\
\hline Eylül 1916 & 4 & Mayıs-Ekim 1924 & 22 \\
\hline Kasım 1918 & 35 & Kasım 1924 & 25 \\
\hline Mart-Haziran 1919 & 30 & Aralık 1924 & 28 \\
\hline Eylül-Kasım 1919 & 20 & Ocak-Temmuz 1925 & 26.50 \\
\hline Haziran-Aralık 1920 & 22 & Ağustos-Eylül 1925 & 25 \\
\hline Mart-Mayıs 1921 & 20 & Mart-Mays 1926 & 24 \\
\hline Haziran-Ekim 1921 & 21 & Eylül 1927 & 19 \\
\hline Kasım-Aralık 1921 & 23 & Ekim 1927 & 20.51 \\
\hline Şubat-Nisan 1922 & 23 & Nisan-Kasım 1928 & 21 \\
\hline Mayıs-Temmuz 1922 & 21 & Şubat-Mayıs 1929 & 23 \\
\hline Ağustos-Ekim 1922 & 19 & Temmuz-Aralık 1929 & 19 \\
\hline Kasım-Aralık 1922 & 17 & Ocak-Şubat 1930 & 18 \\
\hline Mart-Nisan 1923 & 18 & Mart-Mayıs 1930 & 16 \\
\hline Mayıs-Kasım 1923 & 17.25 & & \\
\hline Birim miktarı kilo. & & & \\
\hline
\end{tabular}

2- Hayvan Ûrünleri: Et fiyatunın oluşmasında en önemli unsur herhalde kesimlik hayvan fiyatlanıdır. Canlı hayvanların serbest piyasa fiyatlarına dair bir kayda rastlayamadık. Aslında, hayvan satış fiyatları, piyasanın durgun veya canlı oluşu, arz-talep dengesi, satulacak hayvanın dağda veya ormanda yetiş- 
miş olması ve hayvanların besili olup olmamasına göre oluşmaktaydı. Bu nedenle, her cins hayvan için tek bir fiyat tespit etmek mümkün değildir.

Kasabada zaman zaman kesimlik ve çift hayvanı darlığı oluyordu. Bu darlığın sebeplerinden birisi hayvan hırsızlığıdır. 1917'de kaza sınırları dahilindeki hayvan hırsızlığı dikkati çekecek derecede yaygındı. Çalınan hayvanlar daha ziyade Vezirköprü ve Havza gibi komşu kazalarda satılmaktaydı. Hayvan hırsızlığını önlemek ve alım-satımı kontrol edebilmek için bir pazar mahalli tespit edildi. Burada bir de memur istihdam edildi. Memur, kasabaya getirilen hayvanların kanuna uygun tezkire ve şehâdetnamesinin olup olmadığını kontrol etmek ve hayvanları damgalamakla görevliydi. Pazar harici saulmaya çalışılan hayvanların müsadere edilerek badehaneye kaldırılmasına, bu karara aykırı hareket edenlerin cezalandırılmasına karar verildi. Badehanedeki hayvanlardan kesimlik olanlar et halinde, diğer hayvanlar ise canlı olarak ihtiyaç sahiplerine satılacaktı ${ }^{25}$.

Kasaplar tarafindan hayvan pazarından satın alınan mallar mezbahanede kesilmekteydi. Kesimlik hayvanlardan seferberlik öncesi hayvan başına iki, üç kuruş damga resmî alınıyordu. Ancak, seferberlikte bütün ticarî malların fiyatları yükseldiğinden vergilerin de arturılması yoluna gidildi. Buna göre: Mezbahada kesilen koyun ve keçiden 2, camız ve sığırdan 5, kasaba dışına çıkarılan camız derisinden 10 , sığır derisinden 7.5 , koyun ve keçi derisinden bir kuruş alınması kararlaşturıld $\mathbf{1}^{26}$. Hayvanlar kesim öncesi belediye baytan tarafından muayene edilmekteydi. Mal sahibi bu iş için 1927 yllında hayvan başına 50 kuruş baytariyye ücreti ödüyordu ${ }^{27}$. Kanunen mezbaha haricinde hayvan kesimi yasaktı. Ayrıca, damızlık ve çift hayvanlarının kesimi de yasakt ${ }^{28}$. Bu hükümlere aykırı olarak kesilen hayvanların etleri muhtar, nahiye müdürü veya belediye reisinin emri ile müsadere edilirdi. Müsadere edilen etler fakir fukaraya dağıtulırken hayvan derileri ise müzayede usûlüyle satılarak elde edilen hasılatun Belediye Sandıklarına gelir kaydedilmesi kanun hükmüydü'.

25 1334 tarihli karar: BMKD, I, 258/53.

21. 2 Mart 1337 tarihli karar: BMKD. I, 258/53.

27 10, 27 Aralık 1927 tarihli kararlar: BMKD, II, 26/572; 29/582.

${ }^{28} 24$ Kànûn-ı sânî 1340 tarihli karar: $B M K D$, II, 14/115.

2"! 9 Ağustos 1339 tarihli karar: $B M K D$, I, 311/45; 13 Kânùn-1 ewel 1339 ve 5 Şubat 1928 tarihli kararlar: BMKD, III, 3/85, 49/61. 
Mezbahada kesilen etler, hususî araba ile kasaba dahilinde bulunan kasaplara getirilip dağıtılmaktaydı. Et nakli için 1914 senesinde Bafra Belediyesi tarafından 1.390 kuruş bedelle et nakil arabası yapturıld ${ }^{30}$. Bu işte temizlik işlerinde kullanılan at ve arabacılardan faydalanılmaktaydı. Bu ise, kasabanın temizlik işlerini aksatıyordu. Bu nedenle, sıhhî kurallara uygun olmak şartuyla et nakil işinin müzayede usûlüyle bir kişiye ihalesi kararlaştnlde ${ }^{31}$.

Kasaplar, belediyenin belirlediği narh üzerinden eti satıyorlardı. Narhdan fazlaya et satanlar, hastalıklı hayvan kesenler ile sağlığa zararhı veya ölü hayvan eti satanlar tespit edildiği takdirde nakit para cezasına çarpturıllyorlardi ${ }^{32}$.

Et fiyatlarının yılın belirli zamanlarında tespit edildiği anlaşılmaktadır. Belediye, et narhını borsaya göre belirlemektedir. Genelde, et tüketiminin artuğı Ramazan aylarında, hayvan hastalığı salgını olduğu zamanlarda ve kuzulama ve yavrulama dönemi olan ilkbaharda kasaplık hayvan sayısı azalmaktaydı. Netice itibarıyla et üretimi arzı karşılayamıyordu. Açık, kasaba haricinden getirilen kesimlik hayvanlarla kapatılmaya çalışılıyordu. Bu ise et fiyatlarının yükselmesine sebep oluyordu. Bu nedenle, ilkbahar aylarında et fiyatları ve buna parelel narhda düşmeler tespit edilmekteydi. Ayrıca, savaş yıllarında, talepten fazla üretim yapılamaması, Rum şekaveti sonucu 40 bini aşkın hayvanın telef olması ve hayvan hırsızlığının artması dört nolu tabloda görüldüğü üzere fiyatların sürekli yükselmesine sebebiyet verdi.

Dört nolu tabloda zikredilmeyen ürünler hakkında defterlerde pek fazla malumat yoktur. Bununla birlikte 1917 'de sütün litresi 3 kuruş, âlâ yağlı peynirin kıyyesi 20 kuruş, çerkes peynirinin kıyyesi 12 kuruş, çökeleğin kıyyesi 6 kuruş ve yumurtanın adedi 20 paradır.

${ }^{30} 19$ Nisan 1330 tarihli karar: $B M K D, 1,4 / 15$.

3125 Haziran 1330 tarihli karar: BMKD, I, 32.

323 Mayıs 1330 ve 19 Mart 1339 tarihli kararlar: $B M K D, 1,8 / 29,298 / 8$; 5 Şubat 1928 tarihli karar: $B M K D$ III, 50/62. 


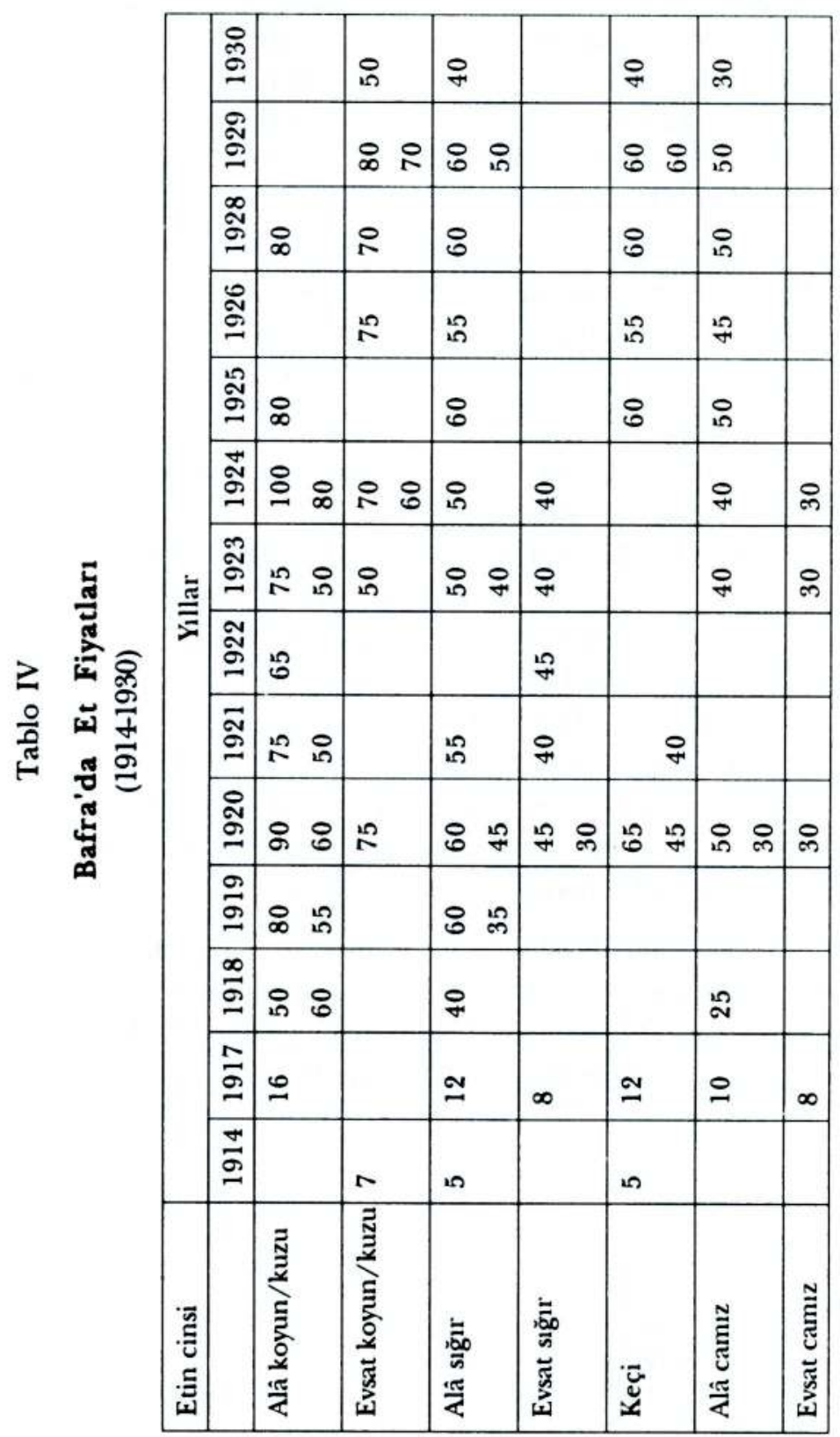




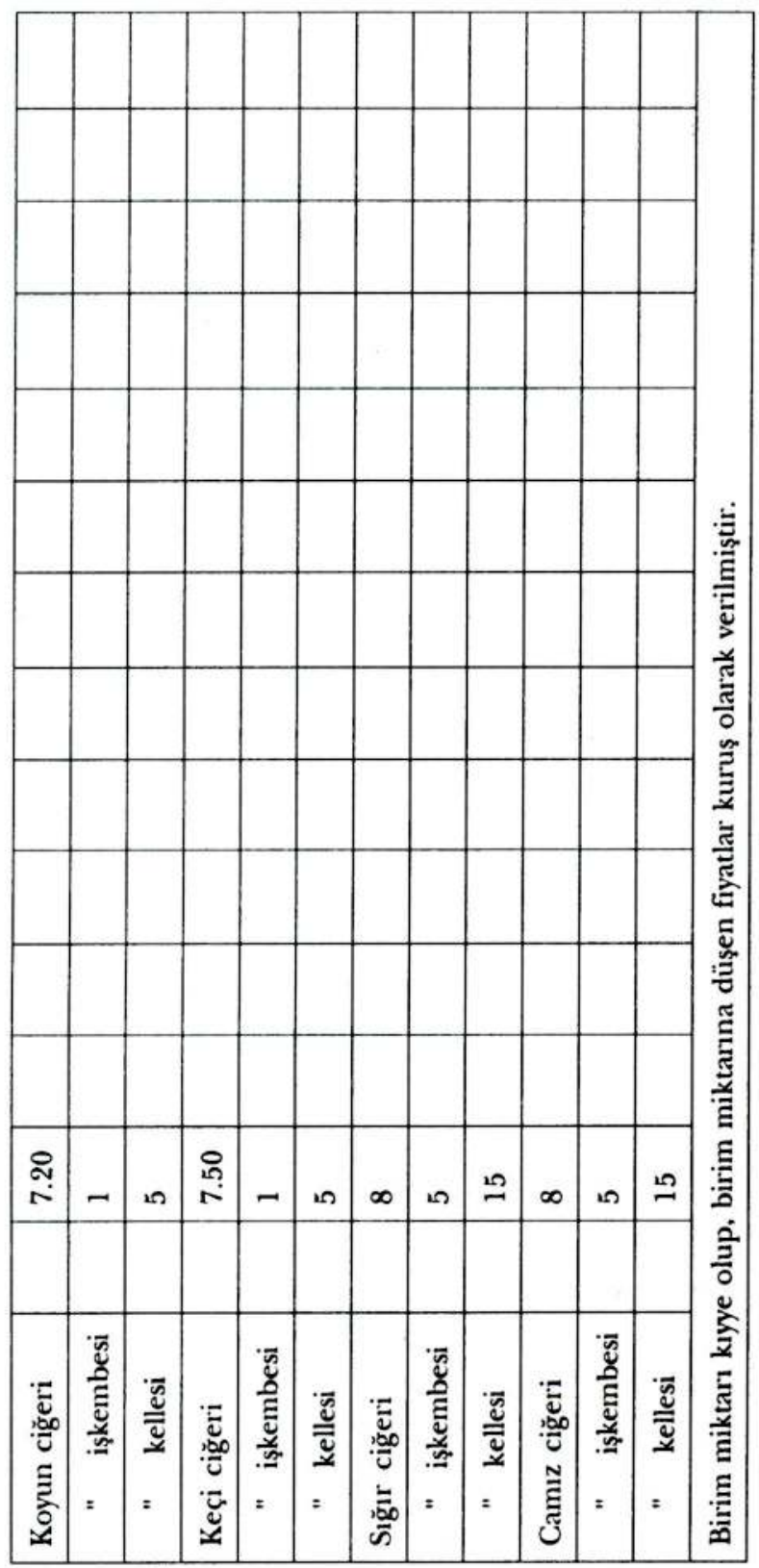


Sadeyağın fiyatu ise beş nolu tabloda görüldüğü üzere mevsimlere göre değişkenlik arz etmektedir. Genellikle haziran-ekim dönemi yağ fiyatlarının en düşük olduğu zamandır. Kasım ayından itibaren yağ fiyatlarının yükselmeye başladığını ve ocak-mayıs arasında fiyatın neredeyse ikiye katlandığını tespit edebiliyoruz.

Tablo V

Sadeyą̆ Fiyatlan

(1917-1930)

\begin{tabular}{|c|c|c|c|c|c|}
\hline Yillar & Aylar & Kuruş & Yillar & Aylar & Kuruş \\
\hline 1917 & - & 60 & 1926 & $\begin{array}{l}\text { Subat } \\
\text { Mart-Nisan } \\
\text { Mayss }\end{array}$ & $\begin{array}{l}234 \\
258 \\
157\end{array}$ \\
\hline 1923 & Aralık & 110 & 1928 & $\begin{array}{l}\text { Ocak } \\
\text { Nisan-Ekim } \\
\text { Kasım-Aralık }\end{array}$ & $\begin{array}{l}195 \\
170 \\
195\end{array}$ \\
\hline 1924 & $\begin{array}{l}\text { Ocak-Şubat } \\
\text { Nisan } \\
\text { Mayıs } \\
\text { Haziran-Temmuz } \\
\text { Ağustos-Ekim } \\
\text { Kasım-Aralık } \\
\end{array}$ & $\begin{array}{l}140 \\
230 \\
200 \\
150 \\
180 \\
200-250 \\
\end{array}$ & 1929 & $\begin{array}{l}\text { Subat-Mayıs } \\
\text { Haziran } \\
\text { Temmuz-Aralık }\end{array}$ & $\begin{array}{l}280 \\
157 \\
172\end{array}$ \\
\hline 1925 & $\begin{array}{l}\text { Ocak } \\
\text { Şubat-Mayıs } \\
\text { Haziran-Eylül } \\
\text { Kasım }\end{array}$ & $\begin{array}{l}312 \\
300-313 \\
170 \\
190\end{array}$ & 1930 & $\begin{array}{l}\text { Ocak-Şubat } \\
\text { Mart } \\
\text { Nisan }\end{array}$ & $\begin{array}{l}188 \\
196 \\
156\end{array}$ \\
\hline
\end{tabular}

3- Meyve, Sebze ve Bakliyat: Kasaba halkı genelde bahçelerinde ürettikleri sebze ve meyveleri tüketmekteydiler. Bu nedenle, hububatta olduğu gibi sebze ve meyvede dışarıya bağımlılık yoktu. Bafra kazası sınırları dahilinde her çeşit ürün yetiştirilebildiğinden sebzenin mutedil bir fiyatla saulması gerekmekteydi. Ancak, 1914 ylının yaz aylannda bazı muhtekirler her tarafta 15 paraya kadar satulan taze fasulyenin kıyyesini 3 kuruşa ve sakız kabağının tanesini de 2 kuruşa satmak cüretinde bulunabiliyorlardı. Söz konusu muh- 
tekirliğin önünü alabilmek için hayvan ürünlerinin yanı sıra sebze ve meyvelere de mevsimine göre fiyat konulması hususunda Belediye reisine yetki verildi ${ }^{33}$.

1914-1920 yılları arasında meyve ve sebze üretiminde kasaba dahilinde herhangi bir kıtlık vak'ası tespit edemedik. Sürekli yağan yağmur ve Müslüman çiftçilerin zorunlu olarak kasabaya göç etmesi sonucu 1921 yılının hasadı bir önceki yıla göre $\% 90$ azaldı. Yetkililer çiftçilere tohumluk zahire, orak ve saban gibi ziraî âlet dağıtmak suretiyle üretimin $\% 30$ nisbetinde artturılmasını plânladılar ${ }^{34}$. Söz konusu darlığın fiyatlara tesirine dair elimizde herhangi bir kayıt bulunmamaktadır.

3312 Haziran 1330 tarihli karar: BMKD, I, 28.

3120 Kânûn-ı eđvel 1337 tarihli karar: BMKD, I, 271/36. 
Tablo VI

Belediye Rayiç Mazbatalanna Göre Meyve, Sebze ve Bakliyat Fiyatlan

(1914-1920)

\begin{tabular}{|c|c|c|c|c|c|c|}
\hline \multirow[t]{2}{*}{ Malın cinsi } & \multirow{2}{*}{$\begin{array}{l}\text { Birim } \\
\text { miktan }\end{array}$} & \multicolumn{5}{|c|}{ Yillar } \\
\hline & & 1914 & 1915 & 1917 & 1919 & 1920 \\
\hline Armut & Kuyye & 0.75 & 0.50 & & & 1 \\
\hline Bakla & $"$ & & & 1.50 & & \\
\hline Bamya & 100 adet & 1.25 & 1 & & & \\
\hline Bezelye & Kiyye & & & 2 & & \\
\hline Ceviz & $"$ & 1.50 & 1 & & & \\
\hline Domates & Kuyye & 0.50 & 0.50 & & & 0.50 \\
\hline Elma & $"$ & 0.50 & 0.25 & & & \\
\hline Enginar & Adet & & 0.50 & 1 & & \\
\hline Erik & Kuyye & & 1 & & & 0.75 \\
\hline Hiyar & Adet & 0.25 & 0.12 & & & 0.12 \\
\hline Ispanak & Kuyye & 2.50 & & & & \\
\hline İncir & $"$ & 0.75 & 0.75 & & & \\
\hline Kabak & Adet & & & 0.75 & & \\
\hline Kara bakla & Kuyye & 1 & & 5 & & \\
\hline Kara kabak & $"$ & 0.25 & 0.25 & & & 0.12 \\
\hline Kara lâhana & $"$ & & & 1.50 & & \\
\hline Kavun/karpuz & 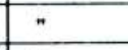 & 1 & 0.75 & & & 0.50 \\
\hline Kestane & $"$ & 1 & 0.75 & & & \\
\hline Kiraz & $n$ & 1.50 & & 5 & & \\
\hline Kuru soğan & $"$ & & 0.75 & & & 1 \\
\hline Lâhana & $"$ & 0.25 & 0.50 & & & \\
\hline Mercimek & $"$ & 1 & 1 & & & \\
\hline Nohut & $"$ & 1 & 1 & 5 & & \\
\hline Patates & $"$ & 0.75 & 0.75 & & 0.20 & 0.87 \\
\hline Pathican & Adet & & 0.50 & & & 0.07 \\
\hline Pazı pancan & Kuyye & & & 1.50 & & \\
\hline Sakız kabağı & Adet & & & & & 0.12 \\
\hline Sarımsak & Kıyye & 2 & 2 & & & 2 \\
\hline Taze fasulye & $"$ & 1.25 & & & & \\
\hline Taze soğan & Bağı & & & 1 & & \\
\hline Üzüm & Kuyye & 1.50 & 2 & & & \\
\hline
\end{tabular}




\section{B- YAKACAK FIYATLARI}

Kasabada halk odun ve kömürle ısınırken aydınlatma için de gazyağı kullanmaktaydı. Resmî kurumlar, yakacak ihtiyaçlarımı ihale usûlüyle temin etmekteydiler ${ }^{35}$. Resmî kurumların ve halkın başlıca yakacak maddesi olan odun kaza sınırları dahilindeki hususî ormanlardan temin edilmekteydi. Ormanlardan elde edilen odunlar öküz arabalarıyla üç saat içinde kasabaya nakledilmekteydi ${ }^{36}$. Odun yüklü öküz arabaları kasaba dahilinde gelişi güzel dolaşturılmak suretiyle odun satışı yapılmaktaydı. Bu karışıklığa son vermek amacıyla, 1915 yılında kasaba dahilinde bir odun pazarının kurulması plânlandi ${ }^{37}$.

Genel savaş esnasında kasaba dahilindeki yakacak fiyatlan hakkında elimizdeki defterlerde herhangi bir kayda rastlamadık. Odunun kilosu 1919 ylının Mart ayında 20, Kasım ayında ise 30 paradır. 1920 yllının ilk on ayında bir kuruş olan odunun kilosu Kasım 1920-Şubat 1922 tarihleri arasında 30 paradır. Odunun kilosu 1922-1930 tarihleri arasında uzunca bir süre bir kuruşa satuld.

Kasabada tüketilen kömürün cinsi ve nereden getirildiğine dair herhangi bir kayda rastlamadık. Kömürün kilosu Kasım 1919'da 5 kuruş iken Mart 1920 'de 12.20 kuruşa kadar yükseldiyse de aynı yılın sonunda 6 kuruşa düştü. 1921-1924 yılları arasında 2.30 ile 7.20 kuruş arasında değişen fiyatlardan işlem gördü.

1914 yılında Canik Sancağı dahilinde gazyağı darlığı vardı. Kasaba yetkililerinin birçok teşebbüsü sonucu Canik Mutasarrıflığı Bafra'ya 150 teneke gazyağı tahsis etti. Söz konusu malı Gazhane Mültezimi İsmail Efendi teneke başına 3 kuruş kâr payı ile kasabaya nakletti. Böylece bir teneke gazyağının maliyeti 31 kuruş 62.5 santime çıkt. Belediye kasaba dahilindeki kimsesizlere sarfetmek üzere teneke başına 8 kuruş zam yaptı. Netice itibarıyla, gazyağının tenekesinin 40 kuruşa satulması kararlaşturıldd ${ }^{38}$.

\footnotetext{
3516 Kasım 1927 tarihli karar: BMKD, III, 17/542.

Shi 21 Mart 1341 tarihli karar: BMKD, II, 106/10.

${ }^{37} 2$ Subat 1331 tarihli karar: BMKD, I, 134.

38 31 Kânûn-ı sânî 1330 tarihli karar: BMKD, I, 53.
} 
Tablo VII

Bafra'da Gazyağı Fiyatları

(1919-1930)

\begin{tabular}{|l|l|l|l|}
\hline Yillar & Kuruş & Yillar & Kuruş \\
\hline 1919 & $22-35$ & 1925 & $38-40$ \\
\hline 1920 & $22-35$ & 1926 & $38-39$ \\
\hline 1921 & $40-50$ & 1927 & $39-40$ \\
\hline 1922 & $25-37$ & 1928 & $39-40$ \\
\hline 1923 & $30-35$ & 1929 & $39-40$ \\
\hline 1924 & $35-40$ & 1930 & $39-40$ \\
\hline \multicolumn{4}{|l}{ Birim miktarı kilo. } \\
\hline
\end{tabular}

\section{C- İNŞAAT MALZEMESİ FIYATLARI}

Bafra kasabasında kamuya ait binaların inşası veyahut tamiri için gerekli malzemeler Belediye Meclisi'nin tespit ettiği rayice göre satın alınmaktaydı. Elimizdeki defterlerde inşaat malzemeleri ile ilgili rayiç listeleri sekiz nolu tablodan anlaşılacağı üzere 1919 tarihinden itibaren başlamaktadır. Bu da seferberlik esnasında Bafra kasabasında kamuya ait binaların tamir edilmediğini göstermektedir. Dört, beş yıllık bir aradan sonra söz konusu binaların tamir edilmesi gündeme geldi. Bu süre zarfunda kasaba dahilinde meydana gelen Rum şekaveti dolayısıyla 120.448 .000 kuruş değerinde 40.149 baş hayvan, 81.636.300 kuruş değerinde 544.242 ölçek hububat yağma edilirken, 8.340.000 kuruş değerinde 278 hane, 2.360 .000 kuruş değerinde 236 ambar, 4.440 .000 kuruş değerinde 222 mağaza, 3.170 .000 kuruş değerinde 317 samanlık ve 350.000 kuruş değerinde 7 değirmen tahrip edilmişti ${ }^{3 !}$.

39! 11 Teşrîn-i evvel 1339 tarihli karar: BMKD, I, 320/54. 


\section{Tablo VIII}

\section{Rayiç Mazbatalarına Göre İnşaat Malzemesi Fiyatlan}

(1919-1928)

\begin{tabular}{|c|c|c|c|c|c|c|c|c|}
\hline \multirow{2}{*}{$\begin{array}{l}\text { Malzemenin } \\
\text { cinsi }\end{array}$} & \multirow{2}{*}{$\begin{array}{r}\text { Birim } \\
\text { miktarı } \\
\end{array}$} & \multicolumn{7}{|c|}{ Yillar } \\
\hline & & 1919 & 1920 & 1923 & 1924 & 1925 & 1926 & 1928 \\
\hline Boya & Kiyye & & & & 100 & & & \\
\hline Çakıl & $\mathrm{m} 3$ & & & & & & & 220 \\
\hline Cimento & Kiyye & & 10 & 16 & 10 & $17 / 12$ & & \\
\hline Çinko & $"$ & 20 & & & $70 / 80$ & 60 & 100 & \\
\hline Çivi & $"$ & & $50 / 60$ & $40 / 32$ & $30 / 35$ & $30 / 35$ & $25 / 32$ & 25 \\
\hline Demir & $"$ & & & & 20 & & & \\
\hline Gömme kilit & Adet & & & & $200 / 250$ & & & \\
\hline Kereste & $\mathrm{m} 3$ & & & & & 6.500 & 6.500 & 5.000 \\
\hline Kilit & Adet & & & 300 & 500 & & & \\
\hline Kireç & Kuyye & & 8 & 7 & $8 / 10$ & $10 / 5$ & & \\
\hline $\begin{array}{l}\text { Kiremit } \\
\text { (Asrupa) }\end{array}$ & Adet & & 10 & & 10 & 20 & 16 & \\
\hline $\begin{array}{l}\text { Kiremit } \\
\text { (yerli) }\end{array}$ & $"$ & 0.8 & 1.1 & $1.4 / 1.2$ & $1.2 / 2$ & 2 & & 2 \\
\hline Kum & Araba & 55 & 55 & $50 / 100$ & 50 & $75 / 100$ & & \\
\hline Kum & m3 & & & & & & 300 & 200 \\
\hline Kurşun & Kiyye & & & & 40 & 55 & & \\
\hline Kürek & Adet & & & & 25 & & & \\
\hline $\begin{array}{l}\text { Kürek ve } \\
\text { maşa }\end{array}$ & 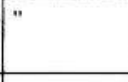 & & & 50 & & & & \\
\hline Menteşe & $"$ & & & $20 / 25$ & 20 & & & \\
\hline $\begin{array}{r}\text { Musluk } \\
\text { (büyük) }\end{array}$ & $"$ & & & & 80 & & & \\
\hline $\begin{array}{r}\text { Musluk } \\
\text { (küçük) }\end{array}$ & $"$ & & & & 40 & & & \\
\hline Sürgü & $"$ & & & 40 & & & & \\
\hline Tahta & $\mathrm{m} 3$ & & & & & & & 6.000 \\
\hline Taş & Araba & & & 100 & & 100 & & \\
\hline Taş & $\mathrm{m} 3$ & 400 & & & & 800 & & \\
\hline Tuğla & Adet & & 1.2 & 1 & 1.2 & $1.3 / 1.5$ & $1.5 / 1.8$ & 1.5 \\
\hline Tutkal & Kiyye & & & 100 & 100 & 120 & & \\
\hline
\end{tabular}


Tespit edebildiğimiz kadarıyla bu dönemde Hükümet Konağı, Jandarma hizmet binası ve cephaneliği, salhane, tevkifhane, Nur-1 İbrahim Camii, Tayyar Paşa hamamı, kasaba dahilindeki mektepler, Ziraat Bankası deposu, askerlik şubesi ve Duhan inhisar idaresi binaları, kanalizasyon ve su şebekesi ile metrûk emvâlin tamir edilmesi söz konusu idi. Bayındırlık faaliyetlerinin 1924 yılında yoğunlaştuğı anlaşılmaktadır.

\section{D- NAKLIYE VE TASSIMA ÜCRETI}

1924 yılına kadar ulaşım ve nakliye vasıtası olarak sadece hayvan gücünden faydalanılmaktaydı. Köylüler, kasabaya binek hayvanları veya arabaları ile gelip gitmekteydiler. Tahsildar ve sihhiye memuru gibi devlet memurları ise kiralık hayvanlarla görev mahalline ulaşmaktaydılar. Herhangi bir memurun görevli olarak köye gitmesi gerektiğinde ilgili devlet dairesi belediyeden rayiç talep etmekteydi. Bu talep üzerine piyasa araşturması yapan Belediye Meclisi hayvanların yevmiye ücretini tespit etmekteydi ${ }^{\dagger 0}$. Belirlenen rayiç ile serbest piyasa arasında fark bulunup bulunmadığına dair elimizde herhangi bir belge bulunmamaktadır.

Nakliyatı dahilî ve haricî nakliyat olmak üzere ikiye ayırabiliriz. Kasabanın ihraç ürünleri Alaçam ve Samsun iskelelerine nakledilmekteydi" ${ }^{\text {" }}$ Posta nakliyatu Bafra-Samsun arasında 1923 yılında haftada üç gün yapılıyordu. 1923 yılında bu iş için aylık 12.000 kuruş sarf ediliyordu ${ }^{12}$. Nakliyat işinde at, katır, merkep, deve, manda, öküz gibi hayvanların yanı sıra tek veya çift hayvanlı arabalar kullanılmaktaydı. Kasaba dahilinde kamuya ait binaların inşası veya tamiratında gerekli olan malzemenin nakli için manda ve öküz gibi yük hayvanı veyahut tek veya çift atlı arabalar kiralanmaktaydı ${ }^{13}$.

${ }^{10}$ Aslında, Vilâyât Belediye Kanunu'na gōre: belediye hududu dahilinde kiralık binek ve yük hayranı ile araba ulaşım ve nakliyat ücreti tarifeleri belediyeler tarafindan tanzim edilecekti. 1293 tarihli Vilâyât Belediye Kanunu: Düstur, I. tertip, IV, İstanbul 1289, s. 538-539.

"BMKD, II, 2/79.

1223 Ağustos 1339 tarihli karar: BMKD, I, 313/48.

${ }^{43}$ Kasabadaki kiralık veya hususî binek ve yük hayram ile arabalardan belediyece belirli bir oranda rüsûm alınmaktaydı. Ancak, mal sahibi rençberlik yapıyorsa veya askerlik hizmetini ifa ediyorsa bu vergiden muaf tutulmaktaydı. 3 Eylül 1332 tarihli karar: BMKD, 1, 152. Hayvan sahipleri hayanlarım kasabada belediye tarafından gösterilen yerlere bağlamak zorundaydılar. Bu kuralı ihläl edenlere para cezası veriliyordu. 12 Temmuz 1339 tarihli karar: BMKD, I, 310/41. Araba sürücülerinin kasaba dahilinde dikkatsizlik sonucu bir kişiyi çiğnemeleri veya yolu tahrip etmeleri nakit para cezasım gerektiren bir suçtu. 28 Mayıs 1340 tarihli karar: BMKD, II, 58/97. 
Kiralık binek hayvanının yevmiye ücreti, yem ve saman masrafı biniciye ait olmak üzere 1921 tarihinde 200 kuruştu "4. Haziran 1922'de ise 170 kuruş olarak tespit edildi. Ancak, hayvan iki veya daha fazla gün için kiralanıyorsa yem ve saman masrafi biniciye ait olmak şartıyla günlük 200 kuruş idi $^{15}$. Temmuz 1923 tarihinde bir çift mandanın yevmiye ücreti 500 kuruş, bir çift öküzün yevmiyesi ise $300 / 400$ kuruştur. 1922 ylında öküz arabası yevmiyesi 400 kuruş, tek atlı araba yevmiyesi 400/500 iken 1923'de 300 kuruş, çift atlı arabanın yevmiyesi ise 600 kuruştur. Hayvanâta en fazla ihtiyaç hissedilen temmuz-aralık döneminde hayvan yevmiye ücretleri artmaktaydı. Örneğin, Temmuz-Aralık 1923 döneminde hayvan yevmiyesi 3 lira olarak tespit edildi "ti. Bafra'dan Samsun'a eşya nakleden hayvan sahiplerine Eylül 1922'de batman başına 15 kuruş ödendi ${ }^{17}$. Yaylı arabanın Bafra-Alaçam arasındaki gidiş dönüş ücreti ise 1924 yılında 18 liradır ${ }^{48}$. 1929 ylında yaz veya kış mevsimi fark etmeksizin at yevmiyesi iki liradır. Yük hayvanlanının 1929 yılı itibarıyla belediye sınırlan dahilinde veya vilâyetler arasındaki bir günlük kazançları belediyenin tespitlerine göre şöyleydi: Çift atlı fayton ve yük arabaları 150 , tek atlı yük arabaları 100, deve ve katır 100, merkep 50 kuruştur ${ }^{1 !}$.

Belediye Karar Defterleri'ndeki kayıtlara nazaran kasaba dahilindeki nakliyat işlerinde 1924 tarihinden itibaren hususî ve ticarî olmak üzere yirmiyi aşkın otomobil ve kamyon gibi motorize araçlar hizmete alındı ${ }^{50} .1929$

4 28 Mays 1337, 2, 31 Kânûn-ı sânî 1337 tarihli kararlar: BMKD, I, 263/91; 255/48; 272/37.

15) 29 Haziran 1338 tarihli karar: BMKD, I, 283/30. Kiralık hayvanlarm maliyetini ortaya koyabilmek için yem masraflarımun da bilinmesi gerekmektedir. Arpa, yulaf, saman ve ot gibi hayvan yemi olarak kullanılan ürūnlerin fiyatları mahsûl ayıın olup olmamasına göre değişkenlik arz etmektedir. Arpanın kilosu 1916'da 30 para, 1917'de 35 para, 1918 ve 1924 yillarmnda 9 kuruş. 1926 yılında ortalama 12 kuruştur. Yulafın kıyyesi ise 1915 ylında 25 para. 1920'de 30 para, kıyahun (taze ot) kıyyesi 1915'de 12 para, 1920'de 15 para, otun kilosu 1924'te 5/8 kuruş. $1925^{\prime}$ te 8 kurus.. 1926 'da 6 kuruş. 1928 'de $5 / 7,1929$ 'da $6 / 9,1930$ 'da $4 / 7$ kuruştur. Samamun kilosu $1919^{\prime}$ da $7,1924^{\prime}$ de $9 / 10,1925$ 'de 9 ve 1926 'da $8,1928^{\prime}$ de $6 / 8,1929$ 'da 10,1930 'da $4 / 7$ kuruş arasında değişmektedir. Bir binek hayanumu bir aỵlı yem ve saman bedeli 1.200 kuruş olarak belirlenmiştir. 24 Mays 1337 tarihli rayiç mazbatası: BMKD, I. 263/8.

1ii 19 Haziran 1339 tarihli karar: BMKD, I, 308/36.

172 Eylül 1338 tarihli karar:BMKD, 1, 286/37.

181 Kânûn-ı sânî 1340 tarihli karar: BMKD. II, 7/95.

19' BMKD, III, 200/148.

5) Belediyeye kaydedilen sōz kouusu vasıtalara vesika ve hususî numara verilınekteydi. Vesika ve hususi numarası olmayan vasıtaların kullanmı yasaku. 25 Ocak 1928 tarihli karar: BMKD. II, 58/99; III. 44/44. Motorlu araçlara park, tamirat ve lastik değişimi için kasaba dahilinde hususî yerler ayrılmaktaydı. Bu aınaçla, Kasım 1927'de kasaba dahilinde beş taka mahalli 
yılında otomobilin bir günlük kirası 20 lira, kamyon kirası ise 25 liradır ${ }^{51}$. Motorlu araçların 1929 ylı itibarıyla belediye sınırları dahilinde veya vilâyetler arasındaki bir günlük kazançlanı belediyenin tespitlerine göre şöyleydi: Binek otomobilleri 2.50, yük otomobilleri 3 liradır $^{52}$.

Kasabada kullanılan diğer bir nakil vasıtası ise kayıklardır. Vezirköprü ve Bafra iskelesi arasında seyr ü sefer eden kayıç̧ılar ve reisleri yevmiye hesabıyla çalışmayıp her sefer için gidiş-dönüş ücreti almaktaydılar. 1924 senesinde bir torba unun nakil ücreti 60 kuruștur. Kayıç̧ılar zaman zaman bu fiyatın iki misli ücret talep edebiliyorlardd ${ }^{53} .1927$ ylında, tayfalar bu iş için yaz aylarında 2.5-4 lira, kıș aylarında ise 4-8 lira arasında bir ücret alıyorlardı. Reisler ise tayfalardan bir lira daha fazla ücret talep ediyorlard $\mathbf{1}^{54} .1929$ yllında belediyenin tespitlerine göre bir kayıkçının günlük kazancı bir liradir ${ }^{55}$.

\section{E- ÜCRETLER}

Kasaba dahilinde çalışan nüfusu asker, memur, çiftçi, tüccar, esnaf, zanaatkâr ve amele şeklinde gruplandırabiliriz. Asker ve memurlar hariç diğer meslek grubunda olanlar belediye tarafindan tutulan deftere kaydolunarak çalışma ruhsatı almakla mükelleftiler. Ruhsatsız iş̧̧i ve usta çalışturan işveren ile ruhsatsız çalışanlar tespit edilmeleri halinde para cezasına çarptırılmaktaydılar ${ }^{5 \mathrm{si}}$.

mevcuttu. 23 Kasım 1927 tarihli karar: BMKD, III, 23/563. Park mahalli olmayan yerlerde ve ózellikłe sokak ve cadde ortasında trafiği aksatacak bir şekilde park etmek veya gidiş-gelişe engel teşkil edecek bir şekilde yaya kaldınımlarının üzerine araba bırakmak kesinlikle men edilmişti. Ticarî arabaların işlerini daha düzenli yapabilmelerini temin maksadıyla terakkuf mahalli adı verilen duraklar yapılmıștu. Durakların önūne konan levhalarda ise durakta en fazla bulunabilecek araç sayısı yazılıydı. Araçlar, sōz konusu duraklarda muayyen bir süre bekliyebiliyorlardı. Yukanda belirtilen yasaklara riayet etmeyen şoförler nakit para cezasına çarpturılmaktaydılar. Suçun tekerrürü halinde ceza mıkdarı artmaktaydı. BMKD, III, 14/531, 38/26; 42/40; 38/28; $39 / 30 ; 45 / 46$.

${ }^{51}$ Temmuz 1929 tarihli karar: BMKD, III, 207/166.

${ }^{52}$ BMKD, III, 200/148.

${ }^{53} B M K D$, II, $16 / 120$.

${ }^{51} B M K D$, III, 16/539.

5x BMKD, III, 295/49.

5i 24 Şubat 1924 ve 22 Mart 1924 tarihli kararlar: BMKD, II, 27/159, 42/43. 
Tüccar ve esnafı tütün tüccarı, hayvan tüccarı, simsar, bakkal, kasap, manifaturacı, uncu, eskici, yağcı, balıkçı, samancı, halıcı, kömürcü, sütçü, pazar esnafı ve seyyar satıcılar ( boğçacı, elbiseci, bıçakçı, orakçı, ipçi, bakırcı, bezci vs.) şeklinde tasnif edebiliriz ${ }^{57}$. Özellikle kasaba dahilinde tütün ticaretiyle meşgul bir hayli sermayedar mevcut olup işyerlerinde pek çok işçi istihdam etmekteydiler ${ }^{58}$. 1929 yllında Bafra kasabasındaki seyyar tüccarlar günde üç lira, hayvan tacirleri ve seyyar satıcılar 50 kuruş kazanmaktayd ${ }^{50}$.

Zanaatkâr ve işçileri aşçı, şekerci, bozacı, çarıkçı, kahveci, çörekçi, yoğurtçu, simitçi, köfteci, limonatacı, şıracı, ekmekçi, hamurkâr, garson, demirci, "perükâr" (berber), arabacı, tuzcu, tabakçı, şerbetçi, balıkçı, saatçı, börekçi, şoför, helvacı, inşaat ustası, dülger, marangoz, taş ustası, sıvacı, badanacı, nakkaş, bozacı, hızarcı, baltacı, lağımcı ve duvarcı şeklinde gruplandırabiliriz ${ }^{\text {ti }}$. Zanaatkârlar meslekteki maharet ve kıdemlerine göre çırak, kalfa, usta veya işbaşı, usta işçi, adî iş̧̧i veyahut birinci sınıf, ikinci sınıf şeklinde kategorilere ayrılmaktaydılaril .

Söz konusu defterlerdeki kayıtlardan anlaşıldığına göre usta ve vasıflı veya vasıfsız ameleler günde 10 saat çalışmakta ve buna karşılık işverenden

${ }^{57}$ Esıafın dükkân ōnüne ticarî mal koymak suretiyle yaya kaldırımlarım işgal etmeleri yasaktı. Yasağa uymayanlar para cezasına çarpturılıyorlardı. Bu cezaya rağmen sōz konusu fillerin ōnüne geçilemediği anlaşılmaktadır. Nisan 1928 tarihli karar: BMKD, III, 68/118. Kahveciler ise kahvehanelerinin önüne gidiş gelişe engel olmayacak bir șekilde ruhsatiye resmî vermek șaruyla sandalye koyabiliyorlardı. 4 Nisan 1928 tarihli karar: BMKD, III, 66/110. Seyyar satucılarm ise sokakların dar olması sebebiyle kasabanın pazar günū olan perşembe günleri haricinde gidiş-gelişi engelleyen sergi açmalan, caddelerde küfe ve tabla ile sațş yapmaları veya üstü açık gıda ürünleri satmaları yasaktı. Sadece eski pazar yerinde belediyeden ruhsat almak şartuyla daimi olarak sergi açabiliyorlardı. Düstur, I. tertip, III, İstanbul 1289, s. 520.

${ }_{58}$ Trabzon Vilayeti Salnamesi 1320, s. 162.

5.) BMKD, III, 295/49.

(1) BMKD, III, 200/148, 295/49.

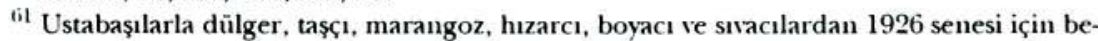
şer lira, karagöz, hokkabaz, cambaz, tiyatro ve sinemalardan gayr-i safi hasılalarından \% 10 , dūkkân levhalan ile tütün tüccan ve birinci sını manifatura mağazalarından beşer lira, ikinci sunf manifatura mağazalarıyla birinci sunf bakkaliye ve kunduracı esnafından üçer lira, ikinci smif bakkaliye ve sair küçük esnafla han, kahvehane, aşçı, kebapçı ve sair esnaftan 50 kuruştan 100 kuruşa kadar, sergilerden beher gün için 100 kuruş resm alınacaktu. Belediye vergi ve resimler kanununun XIV. maddesine göre dükkânlarla ticarî ve sınaî müesseselerinin Türkçe levha asmaları mecburi idi. Yabancı dildeki ifadeler Türkçe metnin altma yazılabilecekti. Ayrıca, levhaların kırmızı zemin üzerine beyaza boyanmış harfler ile yazılması gerektiği müessese sahiplerine tebliğ edilmiştir. 8 Mayıs 1926 tarihli karar: BMKD, II, 182/74; 25 Ocak 1928 tarihli karar: BMKD, III, 43/41. 
dokuz ve on nolu tablolarda belirtilen miktarda yevmiye almaktaydılar ${ }^{62}$. Tablolardan da anlaşılacağı üzere amele yevmiyeleri yaptıkları işlere göre değişkenlik arz etmektedir.

629 Ağustos 1924 tarihli karar: BMKD, II, 74/144. 


\section{Tablo IX}

\section{Usta ve Amele Yevmiyeleri}

(1915-1926)

\begin{tabular}{|l|l|l|l|l|l|l|l|l|}
\hline \multirow{2}{*}{ Meslek } & \multicolumn{7}{|c|}{ Yllar } \\
\cline { 2 - 9 } & 1915 & 1919 & 1920 & 1922 & 1923 & 1924 & 1925 & 1926 \\
\hline Amele & 10 & 80 & $100 / 150$ & $100 / 120$ & $125 / 100$ & $80 / 150$ & $120 / 150$ & $120 / 150$ \\
\hline Badanacı & & & & & 250 & 200 & 300 & \\
\hline Baltacı & & & & 250 & & & & \\
\hline Boyacı & & & & & & 300 & $400 / 500$ & \\
\hline Camcı & & & & & & & 400 & \\
\hline Ceșme ustası & & & & & & & 400 & \\
\hline Civici & & & & & & & 400 & \\
\hline Dam ustası & & & & & & 250 & & \\
\hline Demir ustası & & & & & 300 & 500 & & \\
\hline Durar ustası & & & & 300 & 300 & & $400 / 500$ & $400 / 500$ \\
\hline Dülger & & 200 & 200 & & $200 / 300$ & $200 / 350$ & & \\
\hline Hararcı & & & 200 & & & & & \\
\hline Hızarcı & & & & 250 & & & & \\
\hline Inșat ustası & 25 & & & & & & $300 / 400$ & \\
\hline Kaldırım ustası & & & & & & & & $300 / 400$ \\
\hline Kiremit dizicisi & & & & & 200 & 300 & 300 & \\
\hline Lağımcı & & & & 250 & & 300 & 400 & \\
\hline Marangoz & & 150 & & & & $300 / 500$ & $350 / 400$ & 450 \\
\hline Sıracı & & 150 & & & $250 / 300$ & 300 & 500 & \\
\hline Su yolcusu & & & & & & & & 400 \\
\hline Taș ustası & & 200 & 250 & & $250 / 300$ & $250 / 400$ & 400 & \\
\hline Usta & & & & 400 & 200 & 500 & $300 / 400$ & 400 \\
\hline Yağlı boyacı & & & & & & 400 & & \\
\hline Yevmiveler kuruș olarak verilmiștir. & & & & & \\
\hline
\end{tabular}

Kasaba dahilinde çalışan memurları merkezî idareye bağlı bürokratlar ve belediye çalışanlaıı olmak üzere ikiye ayırabiliriz. Merkeze bağlı bürokratlar : Kaymakam, Tahakkuk memuru, Tahsildar, Müftü, Müezzin, Tahrirat kâtibi, Tapu memuru, Eytam müdürü, Mahkeme baş kâtibi, Zabıt kâtibi, Süvari mübaşiri, Piyade mübaşiri, Gardiyan, Orman memuru, Sıhhiye memuru, Mal müdürü, Mal muavini, Varidat kâtibi ve diğerleridir. Belediyede görev yapan- 
lar ve aylık gelirleri on bir nolu tabloda gösterilmiștir ${ }^{13}$. Savaş yıllarında, belediyede çalışanlara zaman zaman maaşları ödenememiştir ${ }^{\text {ijt. }}$

Tablo X

Usta, Zanaatkâr ve İsçi Yevmiyeleri

(1928-1929)

\begin{tabular}{|c|c|c|c|c|c|}
\hline \multirow[t]{2}{*}{ Meslek } & \multicolumn{2}{|l|}{ Yillar } & \multirow[t]{2}{*}{ Meslek } & \multicolumn{2}{|l|}{ Yillar } \\
\hline & 1928 & 1929 & & 1928 & 1929 \\
\hline $\begin{array}{l}\text { Demetçi: } \\
\text { İş başıları } \\
\text { Usta işçiler } \\
\text { Adî işçiler }\end{array}$ & & $\begin{array}{l}0.60 \\
0.30 \\
0.25\end{array}$ & $\begin{array}{l}\text { Marangoz: } \\
\text { Birinci smıf } \\
\text { İkinci sınıf }\end{array}$ & $\begin{array}{l}4 \\
3\end{array}$ & \\
\hline $\begin{array}{l}\text { Duvarcı: } \\
\text { Birinci sınıf } \\
\text { İkinci sınıf }\end{array}$ & 3 & 4.50 & \begin{tabular}{|l|} 
Nakkaş \\
İş başıları \\
Usta işçiler \\
Adî işçiler \\
\end{tabular} & & $\begin{array}{l}3 \\
2 \\
1 \\
\end{array}$ \\
\hline $\begin{array}{l}\text { Dülger } \\
\text { İş başıları } \\
\text { Usta işçiler } \\
\text { Adî işçiler } \\
\end{array}$ & 3.50 & $\begin{array}{l}2 \\
1.50 \\
1 \\
\end{array}$ & $\begin{array}{l}\text { Sıvacı } \\
\text { İş başıları } \\
\text { Usta işçiler } \\
\text { Adî işçiler } \\
\end{array}$ & & $\begin{array}{l}2 \\
1.50 \\
1 \\
\end{array}$ \\
\hline $\begin{array}{l}\text { Hamal: } \\
\text { Gümrük hamalı } \\
\text { Adî hamal }\end{array}$ & & $\begin{array}{l}1 \\
0.25\end{array}$ & $\begin{array}{l}\text { Taşçı: } \\
\text { İş başılları } \\
\text { Usta işçiler } \\
\text { Adî işçiler } \\
\end{array}$ & & $\begin{array}{l}2 \\
1.50 \\
1 \\
\end{array}$ \\
\hline $\begin{array}{c}\text { Kunduracı: } \\
\text { kalfası } \\
\text { çırağı }\end{array}$ & & $\begin{array}{l}0.25 \\
0.10\end{array}$ & $\begin{array}{l}\text { Tütüncüler: } \\
\text { İş başıları } \\
\text { Usta işçiler } \\
\text { Adî işçiler }\end{array}$ & & $\begin{array}{l}1.50 \\
0.75 \\
0.25\end{array}$ \\
\hline Amele & 1.50 & & Hızarcı & & 1 \\
\hline Aşçıı ustaları & & 1 & Otomobil şoförü & & 1 \\
\hline Dellal & & 0.55 & Simsar & & 0.50 \\
\hline Garson & & 0.25 & & & \\
\hline
\end{tabular}

is3 Bafra Beledi Dairesinin Maaşat Defteri.

'i1 17 Teşrîn-i sânî 1331 tarihli karar: BMKD, I, 126. 
Tablo XI

Belediye Görevlilerinin Maaşlan

(1915-1926)

\begin{tabular}{|l|c|l|l|l|l|l|l|l|l|}
\hline \multirow{2}{*}{ Memuriyet } & \multicolumn{7}{|c|}{ Yillar } \\
\cline { 2 - 9 } & 1915 & 1919 & 1920 & 1921 & 1922 & 1923 & 1924 & 1925 & 1926 \\
\hline Belediye reisi & 1000 & 1000 & 2500 & & & 5000 & 7500 & 7500 & 10000 \\
\hline Kâtip & 400 & & & & & 4500 & 4500 & 5000 & 6000 \\
\hline Kâtip muavini & & & & & & & & & 4500 \\
\hline Sandık emini & & 700 & & & & 4000 & 4000 & 4500 & 5000 \\
\hline Kalfa (mimar-mühendis) & 400 & 800 & 1000 & & & 4000 & 4000 & & 6500 \\
\hline Müfettiş & 500 & 1500 & & & & 3500 & 4000 & & 6000 \\
\hline Müfettiş muavini & & & & & & & 4000 & & 5000 \\
\hline Caruş & 350 & 600 & 1600 & 2500 & 2750 & 3500 & 3500 & 4000 & 4500 \\
\hline Telefon memuru & & & & & & & & & 4500 \\
\hline Odacı & & 600 & & & & 2000 & & & 4000 \\
\hline Şoför & & & & & & & & & 4000 \\
\hline Tenvir memuru & & & & & & & 4000 & & 4500 \\
\hline Tentir memuru muavini & & & & & & & 2500 & & 3000 \\
\hline Tahsildar & & & & & & & & & 5000 \\
\hline Tabip & 1000 & 1500 & & & & 6000 & & & 6000 \\
\hline Ebe & & 600 & & & & & & & 4000 \\
\hline Așı memuru & & 800 & & 1500 & 1500 & 2500 & & & 4000 \\
\hline İtfaiye grup kumandamı & & & & & & & & & 4000 \\
\hline İtfaiye şoförü/makinisti & & & & & & & & & 8000 \\
\hline Tulumbacı & & 500 & & & & & $1500 /$ & & 3000 \\
\hline Dava vekili & & & & & & & 750 & & \\
\hline Temizlik işsisi & & & & & & & 2000 & & 2500 \\
\hline Arabacı & 250 & 1000 & & & & & 2000 & & 2500 \\
\hline Maaşlar lira olarak verilmiştir. & & & & & & & \\
\hline
\end{tabular}




\section{F- KİRA BEDELLERI}

Kira bedelleri konusunda defterlerde teferruath bilgi yoktur. Bununla birlikte, kiralar hakkında bir fikir vermek mümkündür. Örneğin, savaş yıllarında muhacir hastahanesine dönüştürülen bir binaya aylık kira bedeli olarak 1917 'de 200 kuruş ve 1918 'de 500 kuruş takdir kılındı. Keza, askerî hastahaneye dönüştürülen diğer bir binaya da emsaline nisbetle 1916 'da 250 kuruş, 1917 'de 500 kuruş ve 1918 'de 600 kuruş verilmesi kararlaşurıldı ${ }^{65}$. Bu örneklerden hareketle kira bedellerinin savaş yıllarında yıllık \% 100'e varan bir oranda artuğını ifade edebiliriz.

\section{SONUCุ}

1880-1913 arası dünyada olduğu gibi Anadolu'da da fiyat istikrarının bulunduğu bir dönemdir. 1880-1896 arasında tedricen düşen dünya fiyatları asrın sonlarında hafif bir şekilde yükselmeye başladı. Fiyat aruşı genel savaş ile hızlanarak 1920'lere kadar artt. Özellikle ziraî ürünlerin fiyatlarında savaşın başlangıcı ile birlikte anî bir yükselme oldu ${ }^{\text {tit }}$. 1896-1913 arasında ülke genelinde fiyatlar senelik \%1.7 nisbetinde artarken 1913-1914 arasında bu rakam \%9'lara çıkt. 1914-1915 sonrası ekonomik istikrar bozulunca Birinci Dünya Savaşı esnasında paranın satın alma gücü \%85 azaldı. Hayat pahalılığı 19141929 yılları arasında yaklaşık 14 kat artt ${ }^{67}$.

Seferberlik ile müstahsil çağda olan büyük bir kitlenin silâh altuna alınması sonucu ziraî işler kadın, çocuk ve ihtiyarlara kaldı. Orta Anadolu'da yok pahasına satılan hububat ulaşım ağının yeterli olmaması ve nakliyât vasıtalarının ilkelliği sebebiyle zamanında kıtlık sahalarına nakledilemedi. Öte yandan, mevcut yiyecek stoklarının mühim bir kısmı ordunun emrine verildi. $\mathrm{Bu}$ ise, özellikle tüketici toplulukların bulunduğu büyük şehir ve kasabalarda iaşe sıkıntısının çekilmesine, hatta açlık tehlikesinin ortaya çıkmasına sebebiyet verdii' ${ }^{i 8}$. Ziraî üretimin 1915 ve 1916 yıllarında gerilemesi üzerine iaşe meselesi vahim bir durum aldı. Netice itibarıyla Birinci Dünya Savaşı esna-

6.5 19 Mart 1335 tarihli karar: BMKD, I, 200.

tit Vedat Eldem, Osmanlı Imparatorluğı'nun Iktisadi Şartları Hakkında Bir Tedkik, Ankara 1994, s. 131, 133.

ii7 Eldem, Osmanh..., s. 137.

(i8 Muzaffer Lermioğlu, Akçaabat Akçaabat Tarihi ve Birinci Genel Saıaş Hicret Hauralan, İstanbul 1949, s. 188, 208-209. 
sında Anadolu'daki ziraî üretim yarı yarıya azaldı"' ${ }^{6 !}$. Bu durum, 1914'ün sonlarına doğru tüketim maddelerinin fiyatlarının hızla yükselmesine sebep oldu. Trabzon'un Ruslar tarafindan işgali ile sancak dahiline sığınan mülteci sayısının artması iaşe darlığını had safhaya çıkardı. Fiyat aruşlarını önleyebilmek için valilere 1 Mayıs 1916 tarihli muvakkat kanunla zorunlu ihtiyaç maddelerinin satuş fiyatlarını belirleme yetkisi verildi. Buna rağmen, fiyat aruşları 1916 senesinde tedricen devam etti. 1917 yllında ise büyük bir kıtlık ile karşı karşıya kalındı. Kıtlık ve yokluk mevcudu bulunmayan malların fiyatlarını astronomik seviyelere yükseltti ${ }^{70}$. Örneğin, ülke genelinde buğday fiyatları 1914-1917 yılları arasında 14 kat artt. Fiyatlardaki bu dalgalanmayı Bafra kasabasındaki ekmek fiyatlarında da tespit edebiliyoruz. Tevziat sistemindeki aksaklıklar ve serbest piyasada fiyatların astronomik artışı şehir ve kasabadaki fakir ve orta halli nüfusun mağdur olmasına yol açarken varlıklılar ile fakir ve yoksullar arasındaki dengenin büsbütün bozulmasına sebebiyet verdi.

1917 'deki iaşe problemini aşmak amacıyla 5 Nisan 1917'de gıda ve sair ihtiyaç maddelerinin satış ve tevzii kanunu çıkartıldı. Buna göre: Taşrada belediyelere belirleyecekleri ihtiyaç maddelerine azamî fiyat koyabilme ve bunların satıs usûllerini tespit yetkisi verildi. Öte yandan, 1917 tarihli İaşe-i Umumiye Kararnamesi'ne istinaden Ağustos 1917 tarihinde Canik Sancağı'nda İașe Tali Komisyonu oluşturuldu. Komisyon vasıtasıyla, memur ve mültecilere iaşe ambarlarından yiyecek tevzi ediliyordu. Ancak, tevziatun yeterli olmaması üzerine söz konusu kişiler ihtiyaçlarını serbest piyasadan temin etmek zorunda kalıyorlardı. Bu ise piyasadaki talebi arturan bir unsurdu. 1918 yılında savaşın sona ermesi, kasaba dahilindeki mültecilerin memleketlerine dönmeleri ve ithalât kapılarının aralanması gibi gelişmeler sonucu fiyatlarda hissedilir düşüşler olacaktur.

Vasıfsız bir işçi bir günlük kazancı ile 1914 yılında 8 kilo, 1919'da 3.2 kilo, 1923 'de 5.5 kilo, 1929 'da ise 4.7 kilo ekmek alabiliyordu. Vasat bir usta ise günlük kazancı ile 1914 yllında yaklaşık 20 kilo, 1919'da 8 kilo, 1923'te 11 kilo ve 1929 'da 9.5 kilo ekmek alabilmekteydi. Bu mukayesenin de ortaya

69' Vedat Eldem, Harp ve Mütareke Yillarında Osmanlı Imparatorluğu'nun Ekonomisi, Ankara 1994, s. 33, 37.

${ }^{70}$ Nedim İek, " Birinci Dünya Savaşı Esnasında Karadeniz ve Doğu Anadolu'da Cereyan Eden Gōçler ", 19 Mayıs ve Milli Mücadelede Samsun Sempozyumu Bildiriler 16-20 Mayıs 1994, Samsun 1994, s. 88. 
koyduğu üzere ücretlilerin alım gücü düştü. Netice itibarıyla, yevmiyelerin satın alma gücü Millî Mücadele'nin başında \%60, Cumhuriyet döneminin başında \%31-45, 1929 yllında ise \%41-52 nisbetinde azaldı.

Devlet memurlarının maaşlarına 1918 yılına kadar yapılan zamlar maaş seviyelerine göre \%20-50 arasında oynad.. Bütün bu zamlara rağmen memur maaşlarının satun alma güçleri $\% 60-80$ oranında azald ${ }^{71}$. İşçi ve usta yevmiyelerinin aynı tarihler arasındaki satın alma güçlerinin $\% 50$ oranında azaldığını söyleyebiliriz. Bunların devlet memurlarının maaşlarına nazaran fiyat artş̧larına daha iyi intibak ettikleri anlaşılmaktadır. Bunu da savaş döneminde işçi ve ustaya duyulan şiddetli ihtiyaç ile açıklamak mümkündür. Netice itibarıyla, maaş, ücret ve yevmiye ile geçimlerini temin eden kitle savaş müddetince iştira kuvvetini büyük bir oranda kaybetmiş bulunuyordu.

${ }^{71}$ Eldem. Harp re Mütareke Killannda..., s. 54-55. 